\title{
The legal and financial framework
}

'The public library is the responsibility of local and national authorities. It must be supported by specific legislation and financed by national and local governments. It has to be an essential component of any long-term strategy for culture, information provision, literacy and education.'

(IFLA/UNESCO Public Library Manifesto, 1994)

\subsection{Introduction}

Public libraries are a community agency providing access at the local level to a range of knowledge and information for the benefit of the individual and society as a whole. In order to maintain the level of service required to fulfill their functions public libraries should be supported by legislation and sustained funding.

\subsection{The public library and government}

There are many different models of the relationship between public libraries and government. Equally, the laws that govern their activities and funding arrangements are varied and complex. In different countries, provinces, regions, states or municipalities are, either in whole or in part, responsible for library services. As public libraries are a locally based service, local government is often the most appropriate place in the government structure. However, in some countries public libraries are provided at a regional or state level and the national library sometimes has responsibility for providing the public library service. There are instances of two or more levels of government co-operating in the provision of the service. 
- The Estonian Public Libraries Act (1998) detailed the responsibilities of each level of government. It states that the public library is established by the local government body, and that the county or city library is responsible for the co-ordination of library service, interlibrary loans and book mobiles. The local authority is responsible for employees' wages but the funding of library materials is shared between the local authority and the state.

- State Library of Queensland, Australia produced guidelines and standards for Queensland public libraries designed to enhance current practices and to provide achievable goals for public libraries in Queensland (see Appendix 6). <http://www.slq.qld.gov.au/info/publib/build/standards>

- Association of Regional Library Consortium (ARBICON) in Russia was established to coordinate library activities and improve the quality of services by modernizing the management of resources through the merger of library consortia.

<http://www.arbicon.ru/>

\subsubsection{Alternative structures}

In some countries, although the local authority has nominal responsibility for the public library, it does not have the required funds. Therefore, non-governmental organisations or private foundations undertake the practical operation of the public library services. However, to ensure sustained development and its role in the information network, the public library should be closely related to and funded by the appropriate level of government. The eventual aim should be to bring public libraries into the formal government structure operating under national legislation and with appropriate levels of funding.

- Argentina established public libraries and provided these through non-governmental organisations, or organised communities regulated by national legislation.

\subsubsection{National information policies}

In order to make the most effective use of available library and information resources, and take full advantage of the opportunities offered by the development of digital information sources, many coun- 
tries are developing national information policies. Public libraries should be a key element in such policies and public librarians should ensure they are fully involved in their development.

- The CePSE, [Central de Préstec I Serveis Especials] Delivery Center and Special Support Services, focuses its mission on providing services and a professional collection, to ultimately improve the practices and procedures of public and school libraries in Catalonia, Spain. <http://cultura.gencat.cat/cepse>

\subsubsection{E-Government services}

E-Government ( $\mathrm{E}$ is for electronic) strives to engage citizenry in government in a user-centred manner, and thus develop quality government services and delivery systems that are efficient and effective via new technologies. User-centred E-Government suggests that governments will provide services and resources tailored to the actual service and resource needs of users, including citizens, residents, government employees, and others. A key issue for libraries is that citizen-centred EGovernment services may be tasked to local libraries. Public libraries are often identified as optimal partners for provision of E-Government services as they are the most logical public point of access. Additional funds from government should be sought for provision of these services. Adequate equipment, connections, and trained staff with appropriate expertise are necessary.

It is a public library's role to provide public service. Yet in the EGovernment scenario public libraries are sometimes not prepared or forewarned of government closures and elimination of in-person citizen services, with these being transferred to the web. Therefore preparation and policies must be in place as to if or how the library will provide these government services within its mission and available resources. It is recommended to examine staff expertise and current government partnerships to assure optimal preparation is in place for this seemingly inevitable trend occuring in communities.

- The Pasco Public Library Cooperative in FL, USA, has a dedicated E-Government librarian, along with special sections of the library's website that focus on E-Government. For example, the "Online Government Services" page offers most-requested, 
local government, city and municipality, state, and federal government services. <http://pascolibraries.org/>

- The New Jersey State Library, USA, developed a website to assist residents through difficult economic times. The website offers work, financial, housing, health, parental, and senior tools. Each tool offers links to further E-Government information related to that topic. <http://gethelp.njlibraries.org/>

\subsection{Public library legislation}

The establishment of public libraries should be based on legislation, which assures their continuance and place in the government structure. Public library legislation takes various forms. In some countries or regions the legislation is specific to public libraries whereas in others it is part of wider legislation which includes different types of libraries. Public library legislation is also varied in its provisions. It can be simple, allowing the establishment of public libraries but leaving standards of service to the level of government directly responsible for the library, or more complex, with specific detail on what services should be provided and to what standard.

Because governmental structures vary so much in different countries the form and detail of public library legislation is also likely to vary significantly. However, legislation governing public libraries should state which level of government is responsible for provision and how they should be funded. It should also place them in the framework of libraries in the country or region as a whole.

- Mexico and Venezuela have specific public library legislation whereas in Colombia and Brazil legislation on information services includes references to public libraries.

- The Finnish Library Act (1998) stipulates that the public library should be provided by the municipality, either independently or in co-operation with other public libraries, that public libraries should co-operate with other types of libraries and that the municipality should evaluate the library and information services that it provides (see Appendix 2).

- The Constitution of the Republic of South Africa 1996 provided the constitutional framework for the provision of library and information services in South Africa. It lists 'libraries other than national libraries' as an area of exclusive provincial legis- 
lative competence. It is, therefore, a provincial responsibility to develop the legislative framework in which library and information services can be provided.

- In Armenia, local authorities have responsibility for the financing and maintenance of public libraries. The Law on Local Self-Government defined their obligations for maintaining and developing public libraries.

- In the Russian Federation, there are two laws relating to libraries at the federal level, the Library Act and the Legal Deposit Copy Act. These were not concerned solely with public libraries though most of the Library Act is devoted to them.

- The Italian Constitution gives Regions the control of public libraries established by municipalities and provinces. Some Regions issued Library Acts in order to regulate co-operation between libraries and other information, documentation, cultural and educational agencies and to set quality standards.

- Guidelines on library legislation and policy in Europe were issued by the Council of Europe and EBLIDA (European Bureau of Library, Information and Documentation Associations).

\subsubsection{Related legislation}

Public libraries are subject to a range of legislation apart from the specific legislation relating to them. This can include legislation on financial management, data protection, health and safety and staff conditions and there are many other examples. Library managers should be aware of all legislation affecting the operation of the public library.

They should also be aware of global trade negotiations, which can result in policies and agreements, which could have a serious impact on public libraries. In such cases librarians should take every opportunity to bring the effect of such policies on public libraries to the notice of the public and politicians.

\subsubsection{Copyright}

Copyright legislation, especially that relating to electronic publications, is of particular importance to public libraries. It is constantly subject to amendment and review and librarians should keep up-to-date with the legislation in relation to all media. Librarians should promote and support copyright legislation, that achieves an equitable balance between the rights of creators and the needs of users. 
- In the Czech Republic the library association SKIP, acting on its own initiative, participated in the preparation of copyright legislation. After discussions with the Ministry of Culture and the Cultural Committee of the Czech parliament, changes beneficial to libraries were introduced.

\subsubsection{Public lending right}

In some countries, public lending right legislation has been introduced which provides a payment to authors and others involved in the creation of a book, related to its provision in, and loan from, public libraries. It is important that funds for payment of public lending right should not be taken from libraries' funds for the purchase of materials. However, public lending right (PLR), if separately funded, does provide support for authors without affecting public libraries' budgets. In some schemes it can also provide useful statistics on the loans of books by specific authors. Librarians should participate in the development of public lending right schemes to ensure they are not financed from library budgets.

- The Danish government provides funds for PLR payments to Danish authors, translators, artists, photographers and composers who contribute to a printed work. This is defined as cultural support.

<http://www.bs.dk>

- In Australia, the PLR is administered by the Department of the Environment, Water, Heritage and the Arts to make payments to eligible Australian creators and publishers on the basis that income is lost from the availability of their works in public lending libraries. The PLR supports the enrichment of Australian culture by encouraging the growth and development of Australian writing and publishing.

<http://www.arts.gov.au/books/lending_rights/public_lendin

g_right_-_guidelines_for_claimants>

\subsection{Funding}

Adequate levels of funding are crucial to the success of a public library in fulfilling its roles. Without sufficient levels of funding over the longterm it is impossible to develop policies for service provision and make 
the most effective use of available resources. This can be seen in a number of examples: a new library building without adequate funds to maintain it, collections of new books with no money for their replacement and computer systems without funds to maintain and update them. Funding is required not only when a public library is established, but should also be sustained on an assured and regular basis and funding needs made known to community customers.

- A USA library offers a calculator to answer, "What is your library worth to you? How much would you pay out-of-pocket for your library services?"

<http://www.maine.gov/msl/services/calculator.htm>

- The Queensland State Government via the State Library of Queensland outlines the obligations of the provision of a free public library.

<http://www.slq.qld.gov.au/_data/assets/pdf_file/0017/12

2048/SLQ_-_Service_Level_Agreement_-_September_2008. pdf>

- Vladimirskaya Region Universal Scientific Library developed a manual "Paid Services in the Municipal Libraries."

<http://www.library.vladimir.ru/load/metod_03.doc> Examples of annual reports are published on the library website. <http://slib.admsurgut.ru/inf13.htm>

- Central City Children's Library of Kemerovo conducts annual public meetings with readers

<http://www.okrlib.ru/chitatelyam/biblioteka_kak_ona_est/>

to report the work and accomplishments of the libraries, introduce upcoming activities, and share customer data. These reports help substantiate library expenditures.

\subsubsection{Priorities}

A public library and the services it provides is a long-term investment on behalf of the community and should be funded appropriately. It is recognised that even in the wealthiest of societies it may not be possible to provide appropriate levels of funding for every service requirement. It is vitally important, therefore, that service development should be conducted on a planned basis with clear priorities. This process is necessary whatever level of funding is available to the library service. To determine strategic planning and the maintenance of agreed priorities, 
written policy statements should be developed for services. These should be reviewed at regular intervals and revised where necessary.

\subsubsection{Partnerships \& collaborations}

No public library, however large and well funded, can meet all the needs of its customers on its own. Participation in partnerships, collaborations, and networks with other libraries and related organisations, and the provision of access to other sources of information, enables the public library to satisfy the information needs of its users by increasing the range of available resources.

- Queens Borough Public Library, NY, USA, is collaborating with the Brooklyn Children's Museum and the San Francisco, CA, Exploratorium, to bring museum exhibits into the children's room. The project Science in the Stacks seeks to better facilitate hands-on learning of science, math and technology, and make available relevant materials to young customers and their parents in a community where as many as 97 languages are spoken.

<http://www.queenslibrary.org/>

\subsubsection{Sources of funding}

A number of sources of funding are used to finance public libraries but the proportions of funding from each source will vary depending on local factors in each country.

The primary sources are:

- taxation at local, regional or central level

- block grants from central, regional or local level.

Secondary sources of income may include:

- donations from funding bodies or private individuals

- revenue from commercial activities, e.g., publishing, book sales, sale of works of art and handicrafts

- revenue from customer fees, e.g., fines

- revenue from charges to customers for individual services, e.g., photocopying and printing facilities 
- sponsorship from external organisations

- lottery funds for specific initiatives.

\subsubsection{Charging the customer}

The IFLA/UNESCO Public Library Manifesto states: 'The public library shall in principle be 'free of charge'. Charging customers for services and membership should not be used as a source of revenue for public libraries, as it makes the ability to pay a criterion in determining who can use a public library. This reduces access and therefore breaches the fundamental principle that the public library should be available to all. It is recognised that in some countries subscriptions to join the library or charges for specific services are levied. Such charges inevitably deny access to those unable to afford them. They should be seen as an interim situation and not as a permanent feature of public library funding.

It is common in some countries to ask customers to pay a fee or fine when keeping an item after it is due for return to the library. This is sometimes necessary to ensure that items are kept in circulation and not retained for a long time by one customer. The fine should not be set at a level that would deter anyone from using the library. Charges are also sometimes levied for personalized services, for example photocopying or use of a printer. These charges should also not be set at a level which will deter the customer.

\subsubsection{Funding for technology}

Public libraries must, whenever possible, make use of the new technologies to improve services and provide new ones. This means a considerable investment in various kinds of electronic equipment, and a reliance on this equipment for the delivery of services. To continue to perform effectively equipment should be upgraded and replaced. This has significant funding consequences, and a plan for the replacement and upgrading of technological equipment should be developed.

- State Library of Queensland, Australia, outlines a framework for the efficient and effective use of technology as an integral feature of public library services.

<http://www.slq.qld.gov.au/_data/assets/pdf_file/0006/16 2726/SLQ_-_Queensland_Public_Library_Standards_and_Guide lines_-_Technology_Standard_-April_2010.pdf 


\subsubsection{External funding}

Librarians should be proactive in seeking external sources of funding for the public library. However, they should not accept funding from any source if, by so doing, the fundamental status of a public library as an agency available to all is compromised. Commercial organisations, for example, may offer funding with conditions which might prejudice the universal nature of the services provided by the public library. All proposals should be recorded and agreed upon by all parties before enactment.

- The public library in Tarragona, Spain, received funding from business enterprises in the city to run a commercial and economic information service.

- The Chicago Public Library Foundation in the USA is a nonprofit organisation that supports the collections and programmes of the Chicago Public Library. The Foundation has provided start-up funding for new programmes, such as technology, and expanded Sunday and evening service hours. <http://www.chicagopubliclibraryfoundation.org/about/>

\subsection{The governance of the public library}

Public libraries should be governed by a properly established body made up largely of representatives of the local community including those elected either to the local council or to the library board. Library committees and boards should have rules of procedure and their proceedings should be open to the general public. They should meet on a regular basis and publish agenda, minutes, annual reports and financial statements. Normally the governing body will be responsible for matters of policy rather than the day-to-day operation of the library. In all cases the chief librarian should have direct access to the meetings of the governing body of the library and work closely with it. Policy documents should be made available to the public and, where possible, steps should be taken to involve local citizens in the development of the public library.

Public librarians must be fully accountable both to their governing bodies and local citizens for their actions by providing reports, holding public meetings and through consultation. They must also maintain the highest professional standards in carrying out their duties and in advising the governing body. Although the final decisions on policy will 
be taken by the governing body and the librarian, ways should be sought to involve the local citizens who are the actual or potential library customers. The concept of a 'library charter', which identifies and publicises the level of service the public library provides, has been developed in some countries (see Appendix 3 for a sample charter). This establishes a 'contract' between the public library and the customers. Library charters have more credibility if they are developed in consultation with customers.

- A Finnish university library developed technology planning documents for better managing e-services; e-media, and ecollections. Topics include policies for use of equipment; training; telecommunications and bandwidth; filtering access to the web; standards for technology i.e., computers per capita, and equipment replacement plans.

<http://www.docstoc.com/docs/29302907/Joensuu-UniversityLibrary>

- State Library of Queensland, Australia, outlines standards and guidelines for a minimum set of operational services that enable the community effective access to library facilities and the services and collections they offer (see Appendix 6).

\subsection{The administration of the public library}

Public libraries should be well managed and administered. The administration of a public library should be directed towards improving the quality of service to the customers and not as an end in itself. It should be efficient and accountable. To get best results the administrative and management staff of a large public library service should be multidisciplinary, involving staff with specialist skills, for example, librarians, accountants, public relations officers and systems managers. It may also be necessary to draw on the expertise of staff of the parent authority or other related organisation in certain areas, for example, lawyers, payroll and pensions staff.

\subsection{Publicity and promotion}

Public libraries operate in an increasingly complex society, which makes many calls on people's time and attention. It is important, therefore, that libraries publicise their presence and the range of services 
they provide. Publicity ranges from simple techniques, like signs on library buildings stating what they are, and leaflets advertising opening hours and services, to more sophisticated methods like marketing programmes and the use of websites to promote the library's services and activities (see Chapter 7 'The marketing of public libraries').

\section{Resources}

Bertot, J., Jaeger, P., and McClure, C., "Citizen-centered e-government services: benefits, costs, and research needs." Proceedings of the 2008 international conference on Digital government research.

(http:/ / portal.acm.org/ citation.cfm?id=1367832.1367858 accessed 01/01/2010).

IFLA. (n.d.) Public libraries section: Acts on library services. (http://www.ifla.org/V/cdoc/acts.htm accessed 1/01/2010).

IFLA Section of Public Libraries. (1998). The public library as the gateway to the information society: the revision of the IFLA guidelines for public libraries, proceedings of the IFLA/UNESCO Pre-Conference Seminar on Public Libraries, 1997. The Hague: IFLA.

Karppinen, D., and Genz, M. (2004). National information policies: improving public library services? Thesis (M.S.)--Florida State University (http:/ / etd.lib.fsu.edu/theses/available/etd-08232004-225005/ accessed 01/01/2010)

Kretzmann, J., and Rans, S. (2005). The Engaged Library: Chicago Stories of Community Building. Chicago, Ill: Urban Libraries Council.

(http://www.urbanlibraries.org/associations/9851/files/ULC_PFSC_Engaged _0206.pdf accessed 1/01/2010)

Maine State Library. (n.d.). Library use value calculator.

(http://www.maine.gov/msl/services/calculator.htm accessed 1/01/2010).

Online Computer Library Center, Inc. (2008). From awareness to funding: a study of library support in America.

(http:/ / www.oclc.org/reports/ funding/ fullreport.pdf)

Sarkodie-Mensah, K. (2002). Helping the difficult library patron: new approaches to examining and resolving a long-standing and ongoing problem. New York: Haworth Information Press.

Susman, T. (2002). Safeguarding our patrons' privacy: what every librarian needs to know about the USA PATRIOT Act \& related anti-terrorism measures: A satellite teleconference cosponsored by American Association of Law Libraries, American Library Association, Association of Research Libraries, Medical Library Association, Special Libraries Association. Washington, DC: Association of Research Libraries. 
United States Department of Justice. (n.d.). Freedom of Information Act (FOIA) (http://www.justice.gov/oip/ accessed 1/01/2010).

Urban Libraries Council, and The Urban Institute. (2007). Making cities stronger: Public library contributions to local development. (http://www.urban.org/uploadedpdf/1001075_stronger_cities.pdf accessed 1/01/ 2010)

Walker, J., Manjarrez, C. (2003). Partnerships for free choice learning: public libraries, museums, and public broadcasters working together. Washington DC: Urban Institute.

World Intellectual Property Organization. (n.d.). Collection of laws for electronic access (CLEA). (http://www.wipo.int/clea/en/ accessed 1/01/2010).

Woodward, J. (2007). What every librarian should know about electronic privacy. Westport, CT: Libraries Unlimited.

Yarrow, A., Clubb, B., Draper, J., and IFLA Public Libraries Section. (2008). Public Libraries, Archives and Museums: Trends in Collaboration and Cooperation. Professional reports, \#108. The Hague: IFLA.

(http://www.ifla.org/en/publications/ifla-professional-reports-108) 
